\title{
The Development of Social Influence and Aesthetic on Purchase Intention
}

\author{
Alberta Honylia Novitasari Sambe ${ }^{1}$ and Jony Oktavian Haryanto ${ }^{2}$ \\ ${ }^{1,2}$ President University, Jababeka, Bekasi, Indonesia \\ Email address: \\ honylia@gmail.com; jonyharyanto@yahoo.com
}

\begin{abstract}
Due to the development of internet nowadays, people utilize it with games and it results in the development of gaming industries that leads to strong existence of virtual economy. However, the development of the gaming industry in Indonesia was indeed a little late compared to other countries. This study generates a new perspective that describes purchase intention on virtual goods in Massively Multiplayer Online Social Games (MMOSG), Audition, in Indonesia. This research is done through a survey by using questionnaire which acquired 200 Audition players as respondents. The data processing used is structural equation modeling. Results of the study show factors that significantly influence purchase intention on virtual goods are social influence and aesthetic in which purchase intention affects actual purchase behavior, while price utility and satisfaction do not influence purchase intention.
\end{abstract}

Keywords: virtual goods, online games, purchase intention, structural equation modeling, actual purchase.

\begin{abstract}
Abstrak: Dengan adanya perekembangan internet saat ini, masyarakat memanfaatkannya dengan game sehingga mengakibatkan berkembangnya industri game yang mengarah pada eksistensi ekonomi virtual yang kuat. Namun perkembangan industri game di Indonesia sedikit terlambat dibanding negara lain. Penelitian ini menghasilkan perspektif baru yang menggambarkan niat membeli barang virtual dalam Massively Multiplayer Online Social Games (MMOSG) Audition di Indonesia. Penelitian ini dilakukan melalui survei dengan menggunakan kuisioner yang diperoleh 200 peserta audisi sebagai responden. Data diolah dengan structural equation modelling. Hasil penelitian menunjukkan bahwa faktor-faktor yang berpengaruh signifikan terhadap minat beli pada barang virtual adalah pengaruh sosial dan estetika dimana niat membeli mempengaruhi perilaku pembelian aktual, sedangkan utilitas harga dan kepuasan tidak mempengaruhi niat membeli.
\end{abstract}

Kata Kunci: barang virtual, game online, niat membeli, SEM, pembelian aktual.

\section{INTRODUCTION}

Internet was turned into a piece of human life. Currently, internet frequently utilized as entertainment, social communication until business transactions. According to the report from Indonesian Internet Service Provider Association (APJII) as stated in Kompas.com in 2018, out of 262 million people in Indonesia, more than 50\% which is around 143 million 
people, have been connected to the internet in 2017. As times goes by, due to the development of the internet, people utilize it with video games which results to online games (Widiartanto, 2018).

According to (Ferdig, 2008), online games refer to a game that played through several form of computer network, most frequently by using the internet. Online games revolve from simple text-based games to games that integrate graphics through virtual worlds played by many and various players simultaneously from all around the world. Furthermore, (Ho and $\mathrm{Wu}, 2012$ ) stated in their research, online games are generally played by users located in various places. The users use mutual internet connections to exchange information and sharing virtual worlds. In other words, online games are games that use internet connections to process user interactions through virtual worlds.

Based on Forbes, after NPD Group created a profitable business which is entirely supported by selling virtual items, the gaming market started showing profitable income results. Gaming market in the US sells about $\$ 18.8$ billion a year, which half of that sales are coming from PCs or other devices. As times goes by, gaming companies in China and Korea begin to built gaming empire by letting people play for free and selling items from virtual weapons until fashionable outfit that can support players needs and wants (Irwin, 2008).

(Swanner, 2018) stated, in recent years, a lot of game developers have adopted a 'freeto-play' model, allowing users to download their games and play them for free. Online games that in the past used to only serve solely entertainment services, in this modern era began to develop with the feature which allows them to sell virtual items in the game or transfer items to other players, which aims to increase user profits and interests. Agreeing to $(\mathrm{Li}, 2012)$ statement, 'free-to-play' games gave rise to the new economy in the internet era. Especially when users use their real money to obtain virtual items. This action often referred to in-game purchase through real payment transaction.

$(\mathrm{Li}, 2012)$ explained a new economy has emerged in the modern era that attracts a lot of users to use cash to obtain virtual goods. Virtual goods refer to products which are perceived to be truly useful and logically acceptable even though their presence is only virtual. Virtual goods have various functions in the game such as, improve capabilities in the game, provide player needs and wants, or open locked features. These items can also be a core component of the games, including special items and even seasonal items. As time goes by, virtual goods began to develop into beauty items or costumes that can be changed according to the user preferences. The existence of in-game purchases in online games has become popular since game publishers have recognized a golden opportunity in the online gaming industry.

(Matsumoto and Okabe, 2017) stated that Massively Multiplayer Online Games (MMOG) is the one of typical of popular online games. These games are played over the Internet. Players use internet network to interact with other players in the virtual world. Player with other users could create a team to cooperate and compete with other team.

According to (Swastika and Yuwono, 2017), MMOG can be interpreted as a game that has a high graphic in the form of $2 \mathrm{D}$ or $3 \mathrm{D}$ that is played online. Avatar, a digitally formed character created and used by players, can interact with game software and other players in the game. MMOG is divided into various types. Game players in MMOG are categorized into four which are Achievers, Explorers, Socializers, and Killers. Achievers are characters who always try to conquer any challenge to get the best achievement. They 
collect status by defeating challenges in the game. For example is Role Playing (MMORPG) which is the most popular game type. It is made based on a fantasy story and is played to fulfill missions or quests, such as Lineage II or World of Warcraft which is famous throughout the world.

Explorers are characters who are eager to explore new areas, try new things, and discover new combinations. The example is Real-time Strategy Games (MMORTS). This type of game emphasizes the greatness of the player's strategy. This game has a characteristic in which players must manage a world that they create by themselves and set strategies at any time, such as Age of Empires and Star Wars. Socializers are characters who are highly interested in always building relationships with other players by telling stories in the game world. The example is Social Games (MMOSG). MMOSG is a type of game that focuses on the value of socialization. This kind of game usually formed by online communities. In this type of game, the players will more focus on creating their virtual avatars than competing or doing wars. Most famous MMOSG games are Audition, Touch, and Furcadia.

Killers are characters who are always diligent in finding creative ways to disrupt other players' playing experience. For example is First Person Shooter (MMOFPS). This type of game focuses on the aspects of war in the game with the storyline and mission interest, such as Call of Duty and Counter-Strike.

Type of the game that researcher will put the focus on in this research is Audition, which is part of MMOSG (Massively Multiplayer Online Social Game). The game Audition is taken as the object because this game is one of the most popular MMOSG games in Indonesia. Audition is a battle-dance game that carries the theme of fashion, love, and friendship. Each player is allowed to create or join the existing room to interact with others. Because 'fashion' is one of the cores in this game, Audition has shopping features which let players customize the look of their character or avatar. In making avatars in the game, players invest their money and energy to get their 'friendship' or even 'love'. This process is embedded in the economic value from a game developer's perspective, thus the needs of players are the target for gaming industry market. In this research, game players considered as consumers who choose and utilize virtual goods for the sake to fulfill their needs and satisfy their desires in online games.

Moreover, according to (Hudrayasah et al., 2019), even Indonesia is placed in the $17^{\text {th }}$ largest market games in the world, Indonesian games industry still left behind. However, the growth of the gaming industry began to show the result after internet penetration began to increase. 
Figure 1. Demographic Number of Game Players in Indonesia

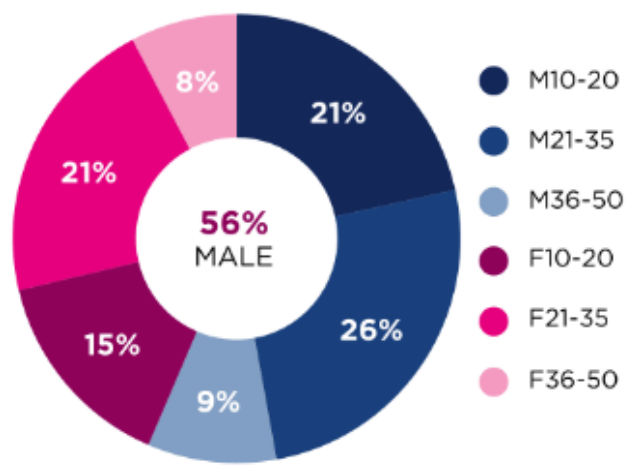

Source: Newzoo, 2017

From the results of research conducted by Newzoo in 2017 as shown in Figure 1, the demographic number of game players in Indonesia was dominated by men aged 21-35 years old. As for women, the largest portion was also held by people aged 21-35. In conclusion, the age of 21-35 years old is the mainland for game companies (Newzoo: Infographic The Indonesian Gamer in 2017, 2017)

Factors that motivate the researcher to conduct this research is because with the population of Indonesia that is more than 260 million people, Indonesia has become a country that has a large market potential for any industries in asia, even the world. However, Indonesia is still incapable of maximizing this opportunity in online game industries. It can be seen from the same research by Newzoo that shows the comparison in Rest APAC region, Indonesia's gaming revenue on 2018 only reached USD 1084 million with 267 million population, lower than Taiwan that only have 267 million population that can reached USD 1231 million. (Newzoo: Top 100 Countries by Game Revenues, 2018) 
Figure 2. Rankings Countries by Game Revenues

\begin{tabular}{|c|c|c|c|c|c|}
\hline RANK & COUNTRY & REGION & POPULATION & $\begin{array}{l}\text { INTERNET } \\
\text { POPULATION }\end{array}$ & $\begin{array}{l}\text { TOTAL } \\
\text { REVENUES } \\
\text { IN US } \\
\text { DOLLARS }\end{array}$ \\
\hline 1 & China & Asia & $1,415 \mathrm{M}$ & $850 \mathrm{M}$ & $\$ 34,400 \mathrm{M}$ \\
\hline 2 & $\begin{array}{l}\text { United States } \\
\text { of America }\end{array}$ & $\begin{array}{l}\text { North } \\
\text { America }\end{array}$ & $327 \mathrm{M}$ & $265 \mathrm{M}$ & $\$ 31,535 \mathrm{M}$ \\
\hline 3 & Japan & Asia & $127 \mathrm{M}$ & $121 \mathrm{M}$ & $\$ 17,715 M$ \\
\hline 4 & $\begin{array}{l}\text { Republic of } \\
\text { Korea }\end{array}$ & Asia & $51 M$ & $48 M$ & $\$ 5,764 \mathrm{M}$ \\
\hline 5 & Germany & $\begin{array}{l}\text { Western } \\
\text { Europe }\end{array}$ & $82 M$ & $76 \mathrm{M}$ & $\$ 4,989 \mathrm{M}$ \\
\hline 6 & $\begin{array}{l}\text { United } \\
\text { Kingdom }\end{array}$ & $\begin{array}{l}\text { Western } \\
\text { Europe }\end{array}$ & $67 M$ & $64 M$ & $\$ 4,731 \mathrm{M}$ \\
\hline 7 & France & $\begin{array}{l}\text { Western } \\
\text { Europe }\end{array}$ & $65 M$ & $58 M$ & $\$ 3,366 \mathrm{M}$ \\
\hline 8 & Canada & $\begin{array}{l}\text { North } \\
\text { America }\end{array}$ & $37 M$ & $34 M$ & $\$ 2,399 \mathrm{M}$ \\
\hline 9 & Spain & $\begin{array}{l}\text { Western } \\
\text { Europe }\end{array}$ & $46 \mathrm{M}$ & $39 M$ & $\$ 2,202 M$ \\
\hline 10 & Italy & $\begin{array}{l}\text { Western } \\
\text { Europe }\end{array}$ & $59 M$ & $40 \mathrm{M}$ & $\$ 2,168 \mathrm{M}$ \\
\hline 11 & $\begin{array}{l}\text { Russian } \\
\text { Federation }\end{array}$ & $\begin{array}{l}\text { Eastern } \\
\text { Europe }\end{array}$ & $144 M$ & $113 M$ & $\$ 1,657 \mathrm{M}$ \\
\hline 12 & Mexico & $\begin{array}{l}\text { Latin } \\
\text { America }\end{array}$ & $131 \mathrm{M}$ & $86 \mathrm{M}$ & $\$ 1,577 M$ \\
\hline 13 & Brazil & $\begin{array}{l}\text { Latin } \\
\text { America }\end{array}$ & $211 M$ & $142 \mathrm{M}$ & $\$ 1,452 \mathrm{M}$ \\
\hline 14 & Australia & Oceania & $25 \mathrm{M}$ & $23 M$ & $\$ 1,293 M$ \\
\hline 15 & Taiwan & $\begin{array}{l}\text { Rest } \\
\text { APAC }\end{array}$ & $24 M$ & $20 \mathrm{M}$ & $\$ 1,231 \mathrm{M}$ \\
\hline 16 & India & $\begin{array}{l}\text { Rest } \\
\text { APAC }\end{array}$ & $1,354 \mathrm{M}$ & $481 \mathrm{M}$ & $\$ 1,105 \mathrm{M}$ \\
\hline 17 & Indonesia & $\begin{array}{l}\text { Rest } \\
\text { APAC }\end{array}$ & $267 M$ & $82 M$ & $\$ 1,084 \mathrm{M}$ \\
\hline
\end{tabular}

Source: Newzoo, 2018

Furthermore, researches that have been devoted to this topic are still limited. Most studies about online games generally only study the characteristics of online game users, motivations for playing online games, desire to play online games, and purchase intention of role-playing and war strategy game.

This study is an empirical investigation of factors that affect purchase intention on virtual goods in socializer games, Audition. The increasing number of potential users leads many companies to involve themselves in this industry which creates a highly competitive business. It forces a company to be able to make the players loyal, have motivation to keep on playing, and intention to buy virtual items presented by the game provider in order to survive.

\section{THEORITICAL REVIEW}

Social Influence. (Guo and Barnes, 2007) explained that when a player perceives participation in a virtual game community as an enjoyable experience, they will have the purchase intention on virtual items to improve their character competencies. The social influence is still a strong predictor of players' behavioral intention to purchase virtual items, especially those who are new to the virtual gaming community. (Jin and Sun, 2015) defined social influence on the virtual world as 'the inner feelings of the interactions with other peoples in the platform through virtual objects'. The 'interactions' are mainly about a function that can be used to interact with people through virtual objects in a virtual world. In this way, social influence refers to the feelings while using the functions of items provided by the platform. 
In previous studies, it is found that users enjoyed the experience more when they felt a stronger social influence while entering a virtual world. When users experience social presence through personal interactions with fellow players, they tend to be deeply absorbed and engaged in the interaction which makes the player feels role-playing undertaken in the virtual worlds more enjoyable (Jin and Sun, 2015).

Prior researches by (Ho and $\mathrm{Wu}, 2012$ ), (Lu et al., 2016), (Hung et al., 2011), and (Guo and Barnes, 2007) show that social influence positively affects purchase intention. It is indicated, when players have the ability to lead the virtual world, the players will feel a strong sense of social presence. This study hypothesizes that social influence within the game positively affects the purchase intention of virtual goods in online games.

\section{H1: Social Influence affect positively on Purchase Intention.}

Price Utility. The price utility of a digital item is obtained from how efficient consumers use the money. According to transaction utility theory, the more favorable the price of a product is to consumers, the greater price advantage that they will feel. It is because consumers assume that the more efficient they use their money for a valuable transaction, the greater the price utility to them which leads to higher purchase intention (Kim et al., 2011). Further, (Ho and Wu, 2012) stated that price utility refers to how reasonable the price offered and the value of virtual goods are to players. It is also related to the function and quality of the virtual goods itself. Consumers tend to choose the product when the utility that will be obtained by consumer suits with the price that they have to pay (Stefany, 2014). Prior researches by (Ho and Wu, 2012) and (Wang, 2010) found that price utility positively affects purchase intention. This study hypothesizes that price utility within the games positively affects the purchase intention of virtual goods in online games.

\section{H2: Price utility affect positively on Purchase Intention.}

Satisfaction. Satisfaction is defined as the response of consumers regarding their fulfillment of needs. It can be categorized as an assessment of features offered by product or service which provide consumers with a level of pleasure related to meeting consumer consumption needs (Bastian, 2015). Meanwhile, (Chen, 2008) stated, satisfaction is an overall response to a comparison of feelings between expectation and perceived feelings after consumption. According to (Ho and $\mathrm{Wu}, 2012$ ), satisfaction of costumers towards products affects purchase intention. Otherwise, customer dissatisfaction will decrease the purchase intention.

Satisfied players will use more virtual items in games and have more expectations about the virtual community. Furthermore, a higher degree of satisfaction will more likely make the players feel that the item they have obtained is worth their money. Thus, the players will more likely to purchase the virtual items to fulfill their expectations that emerges from satisfaction (Jin and Sun, 2015).

Prior researches by (Ho and Wu, 2012), (Bastian, 2015), (Bai et al., 2008), and (Chen, 2008) found that satisfaction positively affects purchase intention. Thus, this study hypothesizes that satisfaction within the games positively affects purchase intention of virtual goods in online games.

\section{H3: Satisfaction affect positively on Purchase Intention.}


Aesthetics. Aesthetics refer to subjective characteristics based on aesthetic values related to the reflection of individual preferences (Shaharudin et al., 2013). This statement also supported by (Shaadiqawati and Yuliati, 2014) that stated aesthetic refers to visually attractive features of a product. Aesthetics are a part of product quality dimension. Product quality dimension that refers to aesthetic is a product characteristic that has the ability to meet individual needs and preferences. Furthermore, a quality dimension is a combination of characteristics and traits which will assess how farther it will fulfill customer needs. (Ho and $\mathrm{Wu}, 2012$ ) also stated in their research that aesthetics are also a part of emotional theory on consumption values for virtual items in online games.

(Shaharudin et al., 2013) and (Ho and $\mathrm{Wu}, 2012)$ found that aesthetics positively affects purchase intention of virtual goods. Thus, this study hypothesizes that aesthetics within the games positively affects on intention to purchase virtual goods in online games.

\section{H4: Aesthetics affects positively on Purchase Intention.}

Purchase Intention. Purchase intention refers to when consumers have a thought that they will buy products or services. Consumers who have intentions to buy specific products will exhibit higher actual buying rates compared to those who do not have intentions to buy at all (Wee et al., 2014). (Permana and Haryanto, 2013) also stated that the intention will be formed when an individual makes a plan to purchase in the future. There are three types of intention constructs which are intention as hope, intention as plan, and intention as desire.

Furthermore, (Guo and Barnes, 2017) stated in their research that purchase intention on virtual worlds refers to the estimation of when consumers will participate in the transaction of virtual goods within games. A lot of prior researches have demonstrated that purchase intention is a significant direct mediator to actual purchase behavior and other factors from actual purchase behavior are fully mediated by purchase intention. In a virtual world, behaviors of purchase intention refers to someone involved in obtaining virtual goods wanted by players (Stefany, 2014). (Jin and Sun, 2015) stated on their research that users' purchase intention of virtual goods may not entirely be determined by technological factors even though they are the only means to facilitate virtual world. The virtual goods purchase behavior may be determined also by the demand.

In conclusion, purchase intention of virtual items refers to the player's desire to obtain particular items through virtual transactions. Prior research from (Stefany, 2014) found that purchase intention significantly supports the actual purchase behavior. This study hypothesizes that purchase intention positively affects actual purchase behavior of virtual goods in online games.

\section{H5: Purchase Intention affect positively on Actual Purchase Behavior.}

Actual Purchase Behavior. (Wee et al., 2014) stated on his research that the theory of planned behavior is when the consumer that has the intention to purchase services or products will indicate higher actual buying rates than those customers who do not have any intention of buying. The intention represent a person's readiness to act the given behavior, and the best predictor of behavior is the intention. According to the theory of reason action, the stronger the intention of a person's to perform a particular behavior, the greater 
purchasing behavior will be performed. Results of studies have explained that the path from intentions of buying a virtual item to the actual purchase behavior is positive and significant. Prior researches by (Wee et al., 2014) and (Stefany, 2014) shown that purchase intention is related positively to actual purchase behavior.

\section{Research Model}

Figure 3. Research Model

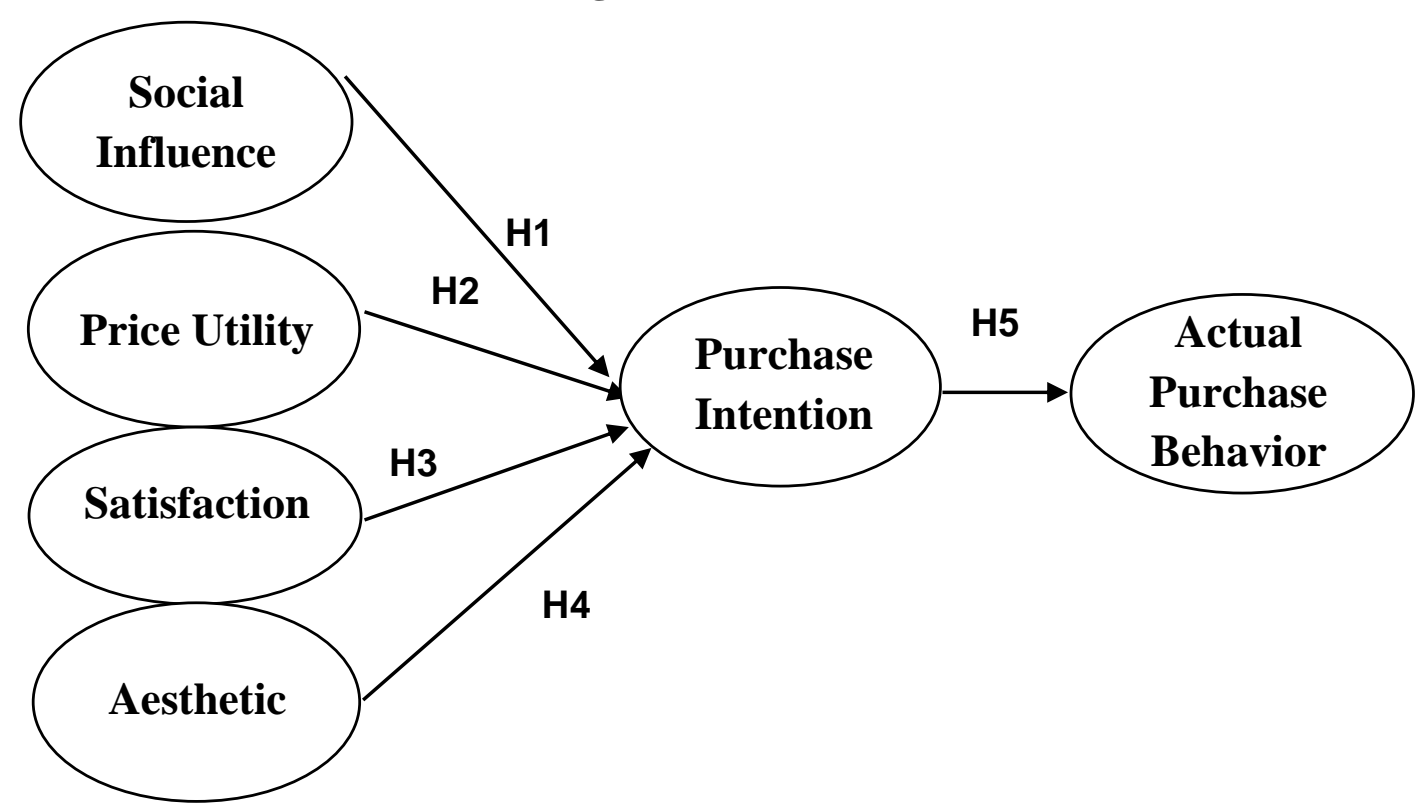

\section{METHODS}

This study using quantitative method. Population in this research are online game users while, the sample used in this study are the users of online game Audition. The sampling technique used in this study is non-probability sampling with convenience technique. The number of sample sizes at least four or five times the number of constructs used in each variables (Permana and Haryanto, 2013). As there are 30 constructs in total, the minimum sample needed in this research is 150 resepondents. Primary data used in this study and were collected by distributing questionnaires online to the users of online game Audition who are the active users of Facebook and Instagram. The data were obtained through field research and self-processed The technique used in this study is quantitative research using SEM (Structural Equation Modeling) with Maximum Likelihood methods.

This table below measure indicator of each variables about social influence, price utility, satisfaction, aesthetic, purchase intention, and actual purchase behavior. The overall observed variables can be seen in Table 1 
Table 1. Observed Variables

\begin{tabular}{|c|c|c|c|}
\hline Variables & Definitions & Indicators & Sources \\
\hline $\begin{array}{c}\text { Social } \\
\text { Influence }\end{array}$ & $\begin{array}{l}\text { the inner feelings of the } \\
\text { interactions with other } \\
\text { peoples in the platform } \\
\text { through virtual objects }\end{array}$ & $\begin{array}{l}\text { Form interpersonal bonds } \\
\text { Make new friends } \\
\text { Maintain relationship } \\
\text { Considered by others } \\
\text { Enhances relationship }\end{array}$ & $\begin{array}{c}\text { (Cheng and Wu, 2012) } \\
\text { and (Souza and Freitas, } \\
\text { 2017) with } \\
\text { modifications. }\end{array}$ \\
\hline Price Utility & $\begin{array}{l}\text { how reasonable the price } \\
\text { offered and the function of } \\
\text { the virtual goods itself }\end{array}$ & $\begin{array}{l}\text { More valuable than the real price } \\
\text { Reasonable price } \\
\text { Good product } \\
\text { Value for money } \\
\text { Economical price }\end{array}$ & (Cheng and $\mathrm{Wu}, 2012$ ). \\
\hline Satisfaction & $\begin{array}{l}\text { The response of consumers } \\
\text { regarding their fulfillment of } \\
\text { needs. }\end{array}$ & $\begin{array}{l}\text { Good gameplay } \\
\text { Satisfying gameplay } \\
\text { Satisfying feature } \\
\text { Satisfying account security } \\
\text { Satisfying decision } \\
\text { Wise choices } \\
\end{array}$ & $\begin{array}{l}\text { (Cheng and Wu, 2012) } \\
\text { and (Bastian, 2015) with } \\
\text { modifications. }\end{array}$ \\
\hline Aesthetic & $\begin{array}{l}\text { Subjective judgment based } \\
\text { on aesthetics value which } \\
\text { related to the reflection of } \\
\text { individual preferences. }\end{array}$ & $\begin{array}{l}\text { Aesthetically appealing } \\
\text { Lovely } \\
\text { Reflect beauty } \\
\text { Aesthetically features } \\
\text { Adorn character virtual }\end{array}$ & $\begin{array}{l}\text { (Cheng and Wu, 2012) } \\
\text { with modifications. }\end{array}$ \\
\hline $\begin{array}{l}\text { Purchase } \\
\text { Intention }\end{array}$ & $\begin{array}{l}\text { Estimation of individual } \\
\text { probability when they will } \\
\text { participate in the transaction } \\
\text { of virtual goods within } \\
\text { games. }\end{array}$ & $\begin{array}{l}\text { Future intention } \\
\text { Likelihood to buy } \\
\text { Willingness to buy } \\
\text { Probability to waste money } \\
\text { High probability to buy }\end{array}$ & $\begin{array}{l}\text { (Cheng and Wu, 2012) } \\
\text { and (Souza Freitas, } \\
\text { 2017) with } \\
\text { modifications. }\end{array}$ \\
\hline $\begin{array}{l}\text { Actual } \\
\text { Purchase } \\
\text { Behavior }\end{array}$ & $\begin{array}{l}\text { The consumer that have } \\
\text { actual buying rates. }\end{array}$ & $\begin{array}{l}\text { Fulfill desire } \\
\text { Regularly buy } \\
\text { Often buy } \\
\text { Adore the items }\end{array}$ & $\begin{array}{l}\text { (Wee et al., 2014) with } \\
\text { modifications }\end{array}$ \\
\hline
\end{tabular}

Previously, a pre-test was conducted to 30 respondents to test the reliability and validity of each construct which would later be used as final research questionnaires in actual research. Descriptive analysis was used in this study to measure construct in each variables. This research measured each indicator by using a six-point Likert scale in which score 1 is defined as Strongly Disagree, 2 as Disagree, 3 as Somewhat Disagree, 4 as Somewhat Agree, 5 as Agree, and 6 as Strongly Agree (Makhriyani, 2012). This scale enables respondents to represent their degrees of agreeing or disagreeing towards each indicator.

The researcher conducted pre-test to find out whether the question of each constructs, filling instruction, and other important factors of the questionnaire can be well understood and accurately represent each variable. The results were used to evaluate, revise, and then redistribute the final research questionnaire to the actual respondents. 
Table 2. Reliability and Validity Pre-test Results

\begin{tabular}{|c|c|c|c|c|}
\hline Variable & Indicator & $\begin{array}{c}\text { Corrected Item-Total } \\
\text { Correlation }\end{array}$ & Cronbach's Alpha & Action \\
\hline \multirow{5}{*}{ Social Influence } & SI1 & .372 & \multirow{5}{*}{.680} & Continue \\
\hline & $\mathrm{SI} 2$ & .512 & & Continue \\
\hline & SI3 & .565 & & Continue \\
\hline & SI4 & .279 & & Revise \\
\hline & SI5 & .499 & & Continue \\
\hline \multirow{5}{*}{ Price Utility } & PU1 & .377 & \multirow{5}{*}{.785} & Continue \\
\hline & PU2 & .510 & & Continue \\
\hline & PU3 & .765 & & Continue \\
\hline & PU4 & .752 & & Continue \\
\hline & PU5 & .445 & & Continue \\
\hline \multirow{6}{*}{ Satisfaction } & $\mathrm{S} 1$ & .739 & \multirow{6}{*}{.891} & Continue \\
\hline & $\mathrm{S} 2$ & .802 & & Continue \\
\hline & S3 & .717 & & Continue \\
\hline & S4 & .511 & & Continue \\
\hline & S5 & .815 & & Continue \\
\hline & S6 & .703 & & Continue \\
\hline \multirow{5}{*}{ Aesthetic } & A1 & .389 & \multirow{5}{*}{.824} & Continue \\
\hline & $\mathrm{A} 2$ & .795 & & Continue \\
\hline & A3 & .816 & & Continue \\
\hline & A4 & .666 & & Continue \\
\hline & A5 & .500 & & Continue \\
\hline \multirow{5}{*}{ Purchase Intention } & PI1 & .769 & \multirow{5}{*}{.881} & Continue \\
\hline & $\mathrm{PI} 2$ & .787 & & Continue \\
\hline & PI3 & .859 & & Continue \\
\hline & PI4 & .430 & & Continue \\
\hline & PI5 & .798 & & Continue \\
\hline \multirow{4}{*}{$\begin{array}{c}\text { Actual Purchase } \\
\text { Behavior }\end{array}$} & AP1 & .800 & \multirow{4}{*}{.884} & Continue \\
\hline & AP2 & .715 & & Continue \\
\hline & AP3 & .833 & & Continue \\
\hline & AP4 & .647 & & Continue \\
\hline
\end{tabular}

Reliability and validity testing were done by looking at the values of Cronbach's Alpha and Corrected Item-Total Correlation. The result of Cronbach's Alpha generated from each variable and Corrected Item-Total Correlation obtained from each indicator. According to (Saidani and Arifin, 2012), the minimum value of Cronbach's Alpha must be above .60. As for the Corrected Item-Total Correlation, the $\mathrm{r}$ value must be higher than $\mathrm{r}$ table. The $\mathrm{r}$ table used in this research is .361. The results of Cronbach's Alpha as seen in Table 2 show all variables exceed minimum requirements which means that all variables are reliable. While from the results of Corrected Item-Total Correlation, SI 4 turned out to be invalid as the value is lower than .361. Therefore, researchers revised the SI4 indicator question from the previous 'Using the virtual goods here makes me become more noticed by others' to 'Using virtual items makes me become more considered by others'. 


\section{RESULTS}

The online questionnaires were distributed through Instagram and Facebook using google spreadsheets in order to facilitate data collection and save time. The researcher managed to collect as many as 200 respondents after passing screening stage. This number has fulfilled the minimum sample size needed which is 150 respondents. After minimum respondents have been collected, the researcher summarizes the respondent profile as shown in Table 3.

Table 3. Profile Respondents

\begin{tabular}{clcc}
\hline Category & \multicolumn{1}{c}{ Sub-category } & Frequency & Percentage (\%) \\
\hline \multirow{2}{*}{ Gender } & Female & 73 & 36.5 \\
& Male & 127 & 63.5 \\
\hline \multirow{3}{*}{ Age } & Under 20 years old & 88 & 44 \\
& Between 21-35 years old & 112 & 56 \\
& Over 35 years old & 0 & 0 \\
\hline \multirow{5}{*}{ Current Education } & Junior High School & 6 & 3 \\
& Senior High School & 71 & 35.5 \\
& College Student & 97 & 48.5 \\
& Bachelor & 26 & 13 \\
\hline \multirow{5}{*}{ Long Game Play in a a } & aess than 10 hours & 87 & 43.5 \\
Week & 20-20 hours & 55 & 27.5 \\
& 20-30 hours & 28 & 14 \\
& $30-40$ hours & 11 & 5.5 \\
& More than 40 hours & 19 & 9.5 \\
\hline
\end{tabular}

Confirmatory factor analysis (CFA) refers to a statistical technique used to verify whether there is a relationship between the indicators and observed variables adopted from prior theory or research (Suhr, 2006). CFA was used in this study because indicators have been grouped into each observed variable. The technique used in this CFA is Convergent Validity. Convergent validity is a test to examine whether the indicators of each variable used are significant in terms of reflecting construct or latent variables (Sukmono and Sudarso, 2011). Convergent validity test consists of standardized loading factor (SLF), construct reliability, and variance extracted.

(Hair et al., 2010) stated that the standardized loading factor (SLF) of the variables observed in the model that meets the good standards is if the value of SLF exceeds .50. If the SLF is lower than .50, the variable indicator has to be removed. As the SLF values of SI5, PU2, and PU3 are below .50, therefore they were all removed. The reliability and validity of this research were done by calculating the construct reliability and variance extracted from the values of standardized loading factors and error variance. According to (Ahmad et al., 2016), the reliability of the model is good if the Construct Reliability exceeds .60 and the validity of the model is good if the Variance Extracted exceeds .50. 
Table 4. Convergent Validity

\begin{tabular}{|c|c|c|c|c|c|}
\hline Variable & Indicator & $S L F$ & Error & $\begin{array}{l}\text { Construct } \\
\text { Reliability }\end{array}$ & $\begin{array}{l}\text { Variance } \\
\text { Extracted }\end{array}$ \\
\hline \multirow{4}{*}{$\begin{array}{c}\text { Social } \\
\text { Influence }\end{array}$} & SI1 & .80 & .35 & \multirow{4}{*}{.87} & \multirow{4}{*}{.63} \\
\hline & SI2 & .90 & .19 & & \\
\hline & $\mathrm{SI} 3$ & .86 & .26 & & \\
\hline & SI4 & .61 & .63 & & \\
\hline \multirow{3}{*}{ Price Utility } & PU1 & .80 & .75 & \multirow{3}{*}{.65} & \multirow{3}{*}{.52} \\
\hline & PU4 & .65 & .57 & & \\
\hline & PU5 & .72 & .48 & & \\
\hline \multirow{6}{*}{ Satisfaction } & $\mathrm{S} 1$ & .84 & .29 & \multirow{6}{*}{.89} & \multirow{6}{*}{.60} \\
\hline & $\mathrm{S} 2$ & .90 & .19 & & \\
\hline & S3 & .80 & .36 & & \\
\hline & $\mathrm{S} 4$ & .57 & .68 & & \\
\hline & S5 & .81 & .35 & & \\
\hline & S6 & .70 & .51 & & \\
\hline \multirow{5}{*}{ Aesthetic } & AE1 & .76 & .43 & \multirow{5}{*}{.87} & \multirow{5}{*}{.59} \\
\hline & AE2 & .78 & .39 & & \\
\hline & AE3 & .84 & .30 & & \\
\hline & AE4 & .84 & .30 & & \\
\hline & AE5 & .59 & .65 & & \\
\hline \multirow{5}{*}{$\begin{array}{l}\text { Purchase } \\
\text { Intention }\end{array}$} & PI1 & .91 & .18 & \multirow{5}{*}{.90} & \multirow{5}{*}{.64} \\
\hline & $\mathrm{PI} 2$ & .95 & .10 & & \\
\hline & PI3 & .68 & .53 & & \\
\hline & PI4 & .62 & .61 & & \\
\hline & PI5 & .82 & .33 & & \\
\hline \multirow{4}{*}{$\begin{array}{c}\text { Actual } \\
\text { Purchase }\end{array}$} & AP1 & .81 & .35 & \multirow{4}{*}{.81} & \multirow{4}{*}{.53} \\
\hline & AP2 & .78 & .38 & & \\
\hline & AP3 & .80 & .37 & & \\
\hline & AP4 & .50 & .75 & & \\
\hline
\end{tabular}

Goodness of Fit Measurement Models. The Goodness of Fit is generated by using LISREL 88 to check whether the values of $p$-value, RMSEA, NFI, NNFI, CFI, IFI, RFI, Standardized $R M R$, GFI, and AGFI which are obtained in output are meet various sizes that will indicate a good match or not. 
Table 5. Goodness of Fit Index

\begin{tabular}{lccc}
\hline \multicolumn{1}{c}{ Indicator } & $\begin{array}{c}\text { Standard Value for } \\
\text { Good Fit }\end{array}$ & Analysis Result & Model Evaluation \\
\hline$p$-value & $\geq .05$ & .00 & Marginal Fit \\
$R M S E A$ & $\leq .08$ & .09 & Marginal Fit \\
$N F I$ & $\geq .90$ & .91 & Good Fit \\
$N N F I$ & $\geq .90$ & .94 & Good Fit \\
$C F I$ & $\geq .90$ & .94 & Good Fit \\
$I F I$ & $\geq .90$ & .94 & Good Fit \\
$R F I$ & $\geq .90$ & .90 & Good Fit \\
$S R M R$ & $\leq .05$ & .10 & Marginal Fit \\
$G F I$ & $\geq .90$ & .76 & Marginal Fit \\
AGFI & $\geq .90$ & .71 & Marginal Fit \\
\hline
\end{tabular}

Figure 4. t-value Diagram

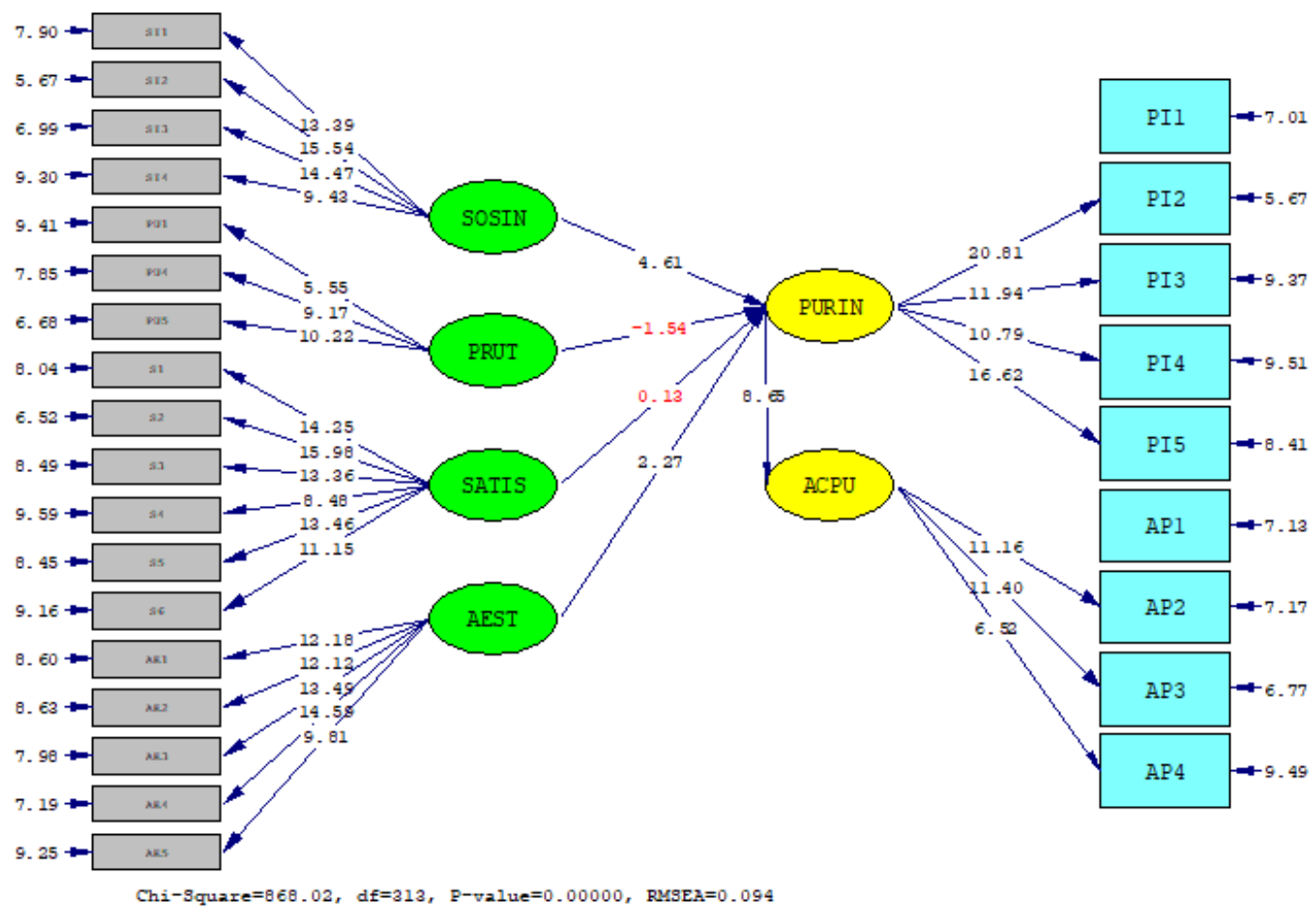

From the structural model obtained, the positive influence of one latent variable with the other latent variables is determined by looking at the $t$-value. When $t$-value exceeds 1.96 , the latent variable gives a positive influence to the other latent variables (Permana and Haryanto, 2013). Conversely, if $t$-value is less than 1.96, the latent variable does not have a significant positive influence on the other latent variables. Table 6 below shows the results regarding the value of $t$ in the structural model that has been processed by the researcher. 
Table 6. Hypotheses Analysis

\begin{tabular}{|c|c|c|c|}
\hline Hypotheses & Hypotheses Statement & T-value & Result \\
\hline $\mathrm{H} 1$ & $\begin{array}{l}\text { Social Influence has a positive effect on Purchase } \\
\text { Intention }\end{array}$ & 4.61 & $\begin{array}{l}\text { Data support the } \\
\text { hypothesis }\end{array}$ \\
\hline $\mathrm{H} 2$ & $\begin{array}{l}\text { Price Utility has a positive effect on Purchase } \\
\text { Intention }\end{array}$ & -1.54 & $\begin{array}{l}\text { Data does not support } \\
\text { the hypothesis }\end{array}$ \\
\hline H3 & $\begin{array}{l}\text { Satisfaction has a positive effect on Purchase } \\
\text { Intention }\end{array}$ & 0.12 & $\begin{array}{l}\text { Data does not support } \\
\text { the hypothesis }\end{array}$ \\
\hline $\mathrm{H} 4$ & $\begin{array}{l}\text { Aesthetic has a positive effect on Purchase } \\
\text { Intention }\end{array}$ & 2.27 & $\begin{array}{l}\text { Data support the } \\
\text { hypothesis }\end{array}$ \\
\hline H5 & $\begin{array}{l}\text { Purchase Intention has a positive effect on Actual } \\
\text { Purchase Behavior }\end{array}$ & 8.65 & $\begin{array}{l}\text { Data support the } \\
\text { hypothesis }\end{array}$ \\
\hline
\end{tabular}

The use of $R^{2}$ or coefficients of determination serves to show how far each variable is able to explain the dependent variable (Saidani and Arifin, 2012). According to (Makhriyani, 2012), the coefficient of determination in structural equations does not have a clear interpretation and to interpret $R^{2}$ as in the regression equation, we must take it from reduced form equations. Based on the reduced form equations of LISREL output, social influence, price utility, satisfaction, and aesthetic on purchase intention has $R^{2}$ value of 0.36 . This shows that $36 \%$ of the purchase intention variants can be explained by social influence, price utility, satisfaction, and aesthetic, while $64 \%$ other variants are explained by other factors which are not discussed in this study. Further, the effect of purchase intention on actual purchase behavior has $R^{2}$ of 0.43 . This implies that $43 \%$ of the actual purchase behavior variants can be explained by purchase intention, while $57 \%$ other variants are explained by other factors which are not discussed in this study.

Hypothesis Analysis. There are five hypotheses in this study. Hypothesis testing analysis was carried out with a 5\% significance level to produce a crisis value $t \pm 1.96$. The hypothesis is accepted if the $t$-value obtained exceeds 1.96 , while the hypothesis is not supported if the t-value obtained is less than 1.96. The following is a summary of the hypothesis test to see if the proposed model is supported by data:

\section{H1: Social Influence affects positively on Purchase Intention.}

Based on the results of Table 6 above, it is found that; social influence has a positive effect on purchase intention as the t-value is 4.61 which fulfills the statistical requirements. In proposing $\mathrm{H} 1$, it is found that social influence is considered as capable of giving a positive influence on purchase intention of the players related to virtual items in game Audition. This is also supported by previous researches by (Lu et al., 2016), (Ho and Wu, 2012), (Hung et al., 2011), and (Guo and Barnes, 2007) who stated that social influence has a positive effect on purchase intention. Researcher presumes it is because players believe that buying a virtual item can help players find new friends, build up, or even maintain a social relationship between players. The better the social influence obtained by the player, the better the effect on the intention to purchase virtual items in Audition game.

\section{H2: Price Utility affects positively on Purchase Intention.}


Based on the results of Table 6 above, it is found that; price utility not support purchase intention as the t-value is -1.54 which does not meet statistical requirements. Therefore, $\mathrm{H} 2$ in this study is not supported. This finding is in line with previous researches by (Kim et al., 2011), (Kim et al., 2009), and (Furnols et al., 2011) who state that price utility does not affect the purchase intention positively. Researcher presumes it could be caused by the majority of respondents who filled out this questionnaire are college students who most of them do not yet have their own income, thus their expenditure is limited.

\section{H3: Satisfaction affects positively on Purchase Intention.}

Based on the results of Table 6 above, it is found that; satisfaction not support purchase intention as the t-value is 0.12 which does not meet statistical requirements. Therefore, H3 in this study is not supported. This is contrary to the research by (Ho and Wu, 2012), (Bastian, 2015), (Bai et al., 2008), and (Chen, 2008) who state that satisfaction has a positive effect on purchase intention. Researcher presumes it could be caused by the majority of respondents who filled out this questionnaire are players who have long game play in a week is less than 10 hours.

\section{H4: Aesthetic affects positively on Purchase Intention.}

Based on the results of Table 6 above, it is found that; aesthetic has a positive effect on purchase intention as the t-value is 2.27 which fulfills the statistical requirements. In proposing $\mathrm{H} 4$, it is found that aesthetic is considered as capable of providing a positive influence on purchase intention of the players related to virtual items in game Audition. Researcher presumes it is because players believe that the virtual items offered are good and aesthetically attractive which make the players to be more recognized in the virtual world and encourage them to buy virtual items. This finding is also supported by previous researches by (Ho and Wu, 2013), (Shaharudin et al., 2013), and (Kim et al., 2011) who state that aesthetic has a positive effect on purchase intention. The better the value of virtual aesthetic items and the ability to reflect the appearance of individual players in the virtual world, the better the effect on the purchase intention of virtual items in the Audition game.

\section{H5: Purchase Intention affect positively on Actual Purchase Behavior.}

Based on the results of Table 6 above, it is found that; purchase intention has a positive effect on actual purchase behavior as the t-value is 8.65 which fulfills statistical requirements. In proposing $\mathrm{H} 5$, it is found that purchase intention is considered as capable of providing a positive influence on actual purchase behavior of players related to virtual items in Audition. Researcher presumes, if the player has intention to buy, actual purchase decisions will arise. This finding is supported by previous researches of (Wee et al., 2014) and (Stefany, 2014) who state that purchase intention has a positive influence to actual purchase behavior. This finding is also supported by the theory proposed by (Wee et al., 2014) of planned behavior which explains that consumers who have intentions to buy products or services will indicate higher actual buying rates compared to those who do not have any intention at all. 


\section{DISCUSSION}

From the results of this study, the t-value used to measure the significance level of price utility with purchase intention is-1.54. It may be concluded that the higher price offered by the producer, the lower their intention to buy virtual goods.

Figure 4. t-value Diagram

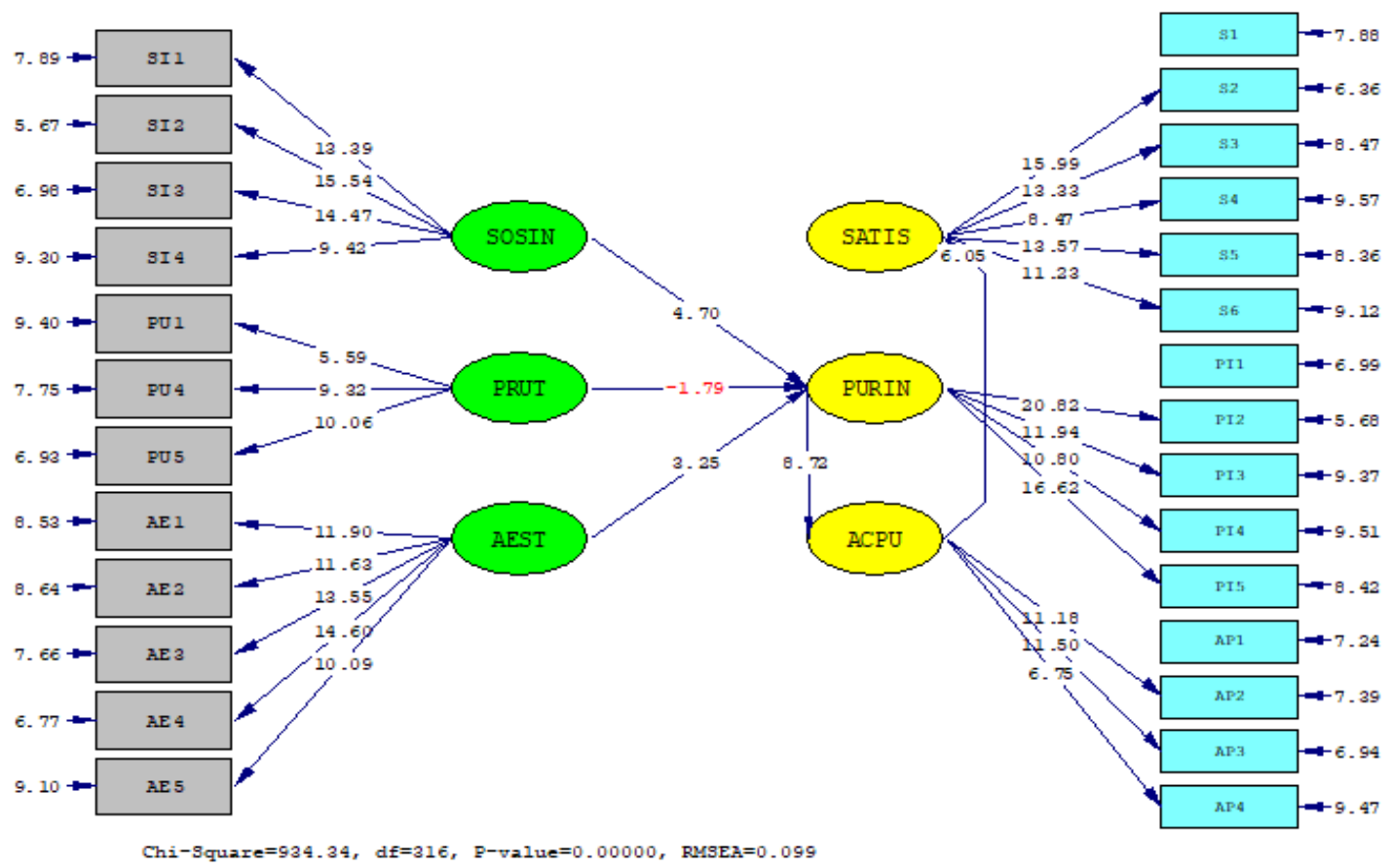

Researcher presumes it is because the majority of respondents are college students who do not have yet income, but allowances. This also supports our common understanding about the negative effect of price toward purchase intention. Our context is virtual goods which is actually considered as non primary product, so it is very logical if price has negative effect towards purchase intention. Furthermore, the researcher also discovered a new phenomenon. Previous studies found that satisfaction of the players affects the purchase intention, while this study found that players satisfaction emerges after their actual purchase. It could be explained that satisfaction is the comparison of expectation and perceived benefits. Thus, in order to be satisfied they have to purchase it first to get the experience and perceived benefits. Researcher presumes it is caused by differences in respondents where in previous studies, satisfaction of the players affects purchase intention on roleplaying game players. Meanwhile, the satisfaction in the socializer game rises after the purchase of the players. The path analysis of this new discovery proven by the results as seen in Figure 4 below.

\section{CONCLUSION}

From the hypothesis analysis above, the researcher concludes that social influence and aesthetics have a positive influence on purchase intention and purchase intention has a 
positive effect on actual purchase behavior. It means that social interaction between players in a virtual world provides a significant contribution to their intention to buy virtual items in Audition games in the future. After the players have the intention, they finally enter the purchase process. In addition, aesthetic factors also contribute significantly to the purchase intention of virtual items in the Audition game in the future. It means that the better the aesthetic value offered related to preferences of each player, the higher the probability of players to have purchase intention of virtual items in game Audition. Meanwhile, price utility and satisfaction do not positively influence in the purchase intention presumably because the respondents in this study are Audition game players which are socializer game players. This finding is in contrast with the previous researches that specifically studied the players of role-playing games. The researcher hopes that this research can be a reference for future studies which discuss social influence, price utility, satisfaction, aesthetics, and purchase intention in its influence on actual purchase behavior.

Managerial Implication. After conducting this research, expectations in the future for PT. Megaxus Infotech as a company that markets Audition game are to strengthen the online gaming market in Indonesia, which has a population over 260 million and huge potential in the gaming industry. The researcher suggests to develop features which are related to players' social relationship by adding player slots in the room, from initially 6 slots to 8 or 10 slots. This development may create or consolidate the relationship among players. With the addition of player slots in the room, it is expected to increase interaction with fellow players through virtual objects in a virtual world. Furthermore, Audition can focus to encourage the players' purchase intention by developing more attractive and aesthetic virtual items that may fulfill individual preferences of players in virtual worlds. The researcher also suggests to offer virtual items that currently in trends, such as creating outfit used by actress or idol who are favored at the time.

\section{REFERENCES}

Ahmad, S., Zulkurnain, N. N., and Khairushalimi, F. I. (2016). Assessing the Validity and Reliability of a Measurement Model in Structural Equation Modeling (SEM). British Journal of Mathematics \& Computer Science , 1-8.

Bai, B., Law, R., and Wen, I. (2008). The Impact of Website Quality on Customer Satisfaction and Purchase Intentions: Evidence from Chinese Online Visitors. International Journal of Hospitality Management , 27 (3), 391-402.

Bastian. (2015). Pengaruh Kompetensi Karakter, Nilai Virtual Item dan Kepuasan Game terhadap Intensi Pembelian Virtual Item dalam Game Online Dota 2. Yogyakarta: Universitas Negeri Yogyakarta.

Brown, M., Pope, N., and Voges, K. (2003). Buying or browsing? An exploration of shopping orientations and online purchase intention. European Journal of Marketing, 37(11/12), 1666-1684.

Chen, C. F. (2008). Investigating Structural Relationships between Service Quality, Perceived Value, Satisfaction, and Behavioral Intentions for Air Passengers: Evidence from Taiwan. Transportation Research Part A: Policy and Practice, 42(4), 709-717.

Ferdig, R. E. (2008). Handbook of Research on Effective Electronic Gaming in Education. New York: Information Science Reference IGI Global. 
Furnols, M. F., Realini, C., Montossi, F., Sañudo, C., Campo, M. M., Oliver, M. A. (2011). Consumer's Purchasing Intention for Lamb Meat Affected by Country of Origin, Feeding System and Meat Price: A Conjoint Study in Spain, France and United Kingdom. ScienceDirect Food Quality and Preference, 22(5), 443-451.

Guo, Y., and Barnes, S. (2007). Why people buy virtual items in virtual worlds with real money. ACM SIGMIS Database: the DATABASE for Advances in Information Systems, 38(4), 69-76.

Hair Jr JF, Black WC, Babin BJ, Anderson RE.(2010). Multivariate Data Analysis: A Global Perspective (7th ed.). Pearson Education International.

Ho, C. H., and Wu, T. Y. (2012). Factors affecting intent to purchase virtual goods in online games. International Journal of Electronic Business Management, 10(3).

Hudrayasah, H., Briantono, N., Fatima, I., Rahadi, R. A. (2019). Marketing Strategy for Game Developer Based on Micro and Macro Environment in Indonesia. Journal of Global Business and Social Entrepreneurship (GBSE), 14(5), 78-92.

Hung, K. P., Chen, A. H., Peng, N., Hackley, C., Tiwsakul, R. A., and Chou, C. L. (2011). Antecedents of Luxury Brand Purchase Intention. Journal of Product \& Brand Management , 20(6), 457-467.

Irwin, M. J. (2008). Forbes. (Forbes Media LLC.) Retrieved November 2018, from How Free Games Make Money: https://www.forbes.com/2008/03/31/free-video-gamestech-personal-cx_mji_0331free.html\#5e45c0a21088.

Jin, W., and Sun, Y. (2015).Understanding the Antecedents of Virtual Product Purchase in MMORPG: An Integrative Perspective of Social Presence and User Engagement. In Pacis (p. 191).

Kaburuan, E. R., Chen, C. H., and Jeng, T. S. (2011). Identifying Users'Behavior on Purchasing Virtual Items. Researchers World, 2(2), 1.

Kim, H. W., Gupta, S., and Koh, J. (2011).Investigating the intention to purchase digital items in social networking communities: A customer value perspective. Information \& Management, 48(6), 228-234.

Kim, H. W., Koh, J., and Lee, H. L. (2009). Investigating The Intention of Purchasing Digital Items in Virtual Communities. PACIS 2009 Proceedings, 18.

Li, Z. (2012). Motivation of Virtual Goods Transactions based on The Theory of Gaming Motivations. Journal of Theoretical \& Applied Information Technology, 43(2).

Lu, H. K., Lin, P. C., and Lin, Y. C. (2016). A study of the factors affecting the purchase intention on mobile game apps. Journal of Advances in Information Technology Vol, 7(4).

Makhriyani, A. (2012). Analisis Pengaruh Store Elements Terhadap Repatronage Decision Dengan Dimediasi Oleh Emotional Response Dan Overall Evaluation Pada Restoran Etnis Jawa Mbah Jingkrak. Library Automation and Digital Archive of Universitas Indonesia Library .

Matsumoto, K. and Okabe, Y. (2017). A Collusion-resilient Hybrid P2P Framework for Massively Multiplayer Online Games. In Proceedings - 2017 IEEE 41st Annual Computer Software and Applications Conference, 342-347.

Newzoo: Infographic The Indonesian Gamer in 2017. (2017, June 1). Retrieved 12 1, 2018, from Newzoo: https://newzoo.com/insights/infographics/the-indonesian-gamer$\underline{2017 \%}$. 
Newzoo: Top 100 Countries by Game Revenues. (2018, December). Retrieved January 2019, from Newzoo: https://newzoo.com/insights/rankings/top-100-countries-bygame-revenues/.

Permana, M. S., and Haryanto, J. O. (2013). Pengaruh Country of origin, Brand Image Dan Persepsi Kualitas Terhadap Intensi Pembelian. Jurnal ManajemenUntar, 18(3).

Priambada, A. (2015). Peluang dan Tantangan yang Harus Dihadapi Pemain Industri Game di Indonesia. Retrieved from DailySocial: https://dailysocial.id/post/peluangdan-tantangan-yang-harus-dihadapi-pemain-industri-game-di-indonesia/.

Saidani, B., dan Arifin, S. (2012). Pengaruh kualitas produk dan kualitas layanan terhadap kepuasan konsumen dan minat beli pada ranch market. JRMSI-Jurnal Riset Manajemen Sains Indonesia, 3(1), 1-22.

Shaadiqawati, N., dan Yuliati, A. L. (2014). Pengaruh Kualitas Produk Dan Harga Kamera Tipe Digital Slr Merek Canon Terhadap Keputusan Pembelian (Studi Pada Perusahaan Canon Di Jl. Banda Bandung). eProceedings of Management, 1(3).

Shaharudin, M. R., Mansor, S. W., Hassan, A. A., Omar, M. W., and Harun, E. H. (2013). The relationship between product quality and purchase intention: The case of Malaysias national motorcycle/scooter manufacturer. African Journal of Business Management, 5(20), 8163-8176.

Souza, L. L., and Freitas, A. A. (2017). Consumer Behavior of Electronic Games' Players: A Study on The Intentions to Play and to Pay. Revista de Administração , 52(4), 419430.

Stefany, S. (2014).The effect of motivation on purchasing intention of online games and virtual items provided by online game provider. CommIT (Communication and Information Technology) Journal, 8(1), 22-27.

Suhr, D. (2006). Exploratory or Confirmatory Factor Analysis. SAS Users Group International Conference (pp. 1 - 17). Cary: SAS Institute, Inc.

Sukmono, R. A., dan Sudarso, I. (2011). Analisa Pengaruh Bauran Pemasaran dan Kualitas layanan terhadap Loyalitas pelanggan dengan Metode Structural Equation Modeling (Studi Kasus: BNI Cabang Tanjung Perak Surabaya. In Prosiding Seminar Nasional Manajemen Teknologi XIII (pp. 1-10).

Swanner, N. (2018). Here's How Game Developers Make Money in 2018. Retrieved from Dice: https://insights.dice.com/2018/10/04/game-developers-making-money-2018/.

Swastika, H., dan Yuwono, A. I. (2017). Pemain Game Membeli Barang Virtual: Studi Etnografi Mengenai Motivasi Pembelian Barang Virtual di dalam Game yang Dilakukan Oleh Pemain Game Daring Audition . Electronic Theses \& Dissertations Gadjah Mada University .

Wang, E. S. T. (2010). Impact of multiple perceived value on consumers' brand preference and purchase intention: a case of snack foods. Journal of Food Products Marketing, 16(4), 386-397.

Wee, C. S., Ariff, M. S., Zakuan, N., and Tajudin, M. N. (2014). Consumers Perception, Purchase Intention and Actual Purchase Behavior of Organic Food Products. Review of Integrative Business and Economics Research , 3(2), 378.

Widiartanto, Y. H. (2018). Potensi Industri Game Indonesia Rp 11 Triliun, Tapi Belum Tergarap. Retrieved from Kompas.com: https://ekonomi.kompas.com/read/2018/03/21/061500826/potensi-industri-gameindonesia-rp-11-triliun-tapi-belum-tergarap. 